COMUNICAÇÃODOS EDITORES

\title{
Nova dinâmica redatorial para a Acta Cirúrgica Brasileira
}

\author{
Saul Goldenberg ${ }^{1}$ \\ Luiz Francisco Poli de Figueiredo ${ }^{2}$ \\ Ruy Guilherme Rodrigues $\mathrm{Cal}^{3}$
}

A Acta Cirúrgica Brasileira tem se empenhado em selecionar artigos de relevância..

O número cada vez maior de artigos submetidos à avaliação pelo Corpo Editorial da ACTA, deixou evidente a necessidade de aperfeiçoar o modelo do fluxo de analise dos trabalhos. Para mais rápida e eficiente comunicação entre os autores, editores e revisores tornou-se imperiosa a implantação de novo modelo de comunicação eletrônica.

A Internet é o instrumento que mais rápido movimenta a informação de forma fácil e compartilhada.

Neste sentido a missão da ACTA é oferecer aos colegas da área de saúde, aos pesquisadores e ao Corpo Editorial a versão eletrônica que permitirá o uso da informática e da Internet a favor da eficiência do periódico.

A “Acta Web" já esta disponível aos colegas para servir de interface entre todos os usuários. Facilita-se desde a simples consulta aos artigos publicados, a remessa de trabalhos e todo o fluxo de analise. Após aprovação tornar-se-a possível o acompanhamento contínuo pelos autores e pelo Corpo Editorial.
Para acessar utiliza-se o endereço eletrônico www.mdview.com.br/acb seguindo as etapas: 1) Escolha o idioma; 2) Selecione Submeter artigos; 3)Entre com o seu Login e Senha [provisórios. Ex. Login=seu primeiro nome e repete na Senha. Será enviado depois o seu Login e senha definitivos]; 4) Cadastre-se [nome e e-mail obrigatórios] para submeter seu cadastro a aprovação. Após aprovação o usuário receberá por e-mail Login e Senha, com as quais poderá entrar no sistema para enviar artigos e acompanhar o fluxo de analise.

São comuns dificuldades e problemas inerentes ao início da utilização do sistema, que deverão ser sanadas com o seu funcionamento. O usuário encontrará sempre um canal aberto de comunicação com o editores. Para esclarecimentos de dúvidas e ajuda utilize a opção "Fale conosco" ou "Fale com Editor".

Nesta fase inicial as orientações poderão ser solicitadas pelo e-mail ruycal@uol.com.br

As sugestões dos usuários serão bem-vindas para o aperfeiçoamento do sistema.

Para acessar utiliza-se o endereço eletrônico www.mdview.com.br/acb seguindo as etapas:

1) Escolha o idioma;

2) Selecione Submeter artigos;

3) Entre com o seu Login e Senha [provisórios.Ex Login=seu primeiro nome e repete na Senha. Será enviado depois o seu Login e senha definitivos];

4) Cadastre-se [nome e e-mail obrigatórios] para submeter seu cadastro a aprovação. Após aprovação o usuário receberá por e-mail Login e Senha, com as quais poderá entrar no sistema para enviar artigos e acompanhar o fluxo de analise.

São comuns dificuldades e problemas inerentes ao início da utilização do sistema, que deverão ser sanadas com o seu funcionamento. O usuário encontrará sempre um canal aberto de comunicação com os editores. Para esclarecimentos de dúvidas e ajuda utilize a opção "Fale conosco" ou "Fale com Editor". Nesta fase inicial as orientações poderão ser solicitadas pelo e-mail ruycal@uol.com.br

1. Fundador e Editor Científico.

2. Co-Editor Científico.

3. Editor Associado. 